\title{
Relevance of Entreprenuership Curriculum to Engineering Education in Nigeria
}

\author{
Bashir Garba I. ${ }^{1, *}$, Laminu S. Kuburi ${ }^{2}$, F. O. Anafi ${ }^{2}$ \\ ${ }^{1}$ Department of Maintenance and Services, Ahmadu Bello University, Zaria, 234, Nigeria \\ ${ }^{2}$ Department Mechanical Engineering, Ahmadu Bello University, Zaria, 234 Nigeria
}

\begin{abstract}
Engineering entrepreneur is of great importance to know about him on the basis of individual consideration. These consideration give him ample scope to face his own self by asking the question "Who I am?" If he can give meaningful answer to this complex question with exemplary courage and utter personal disregard to being exposed, then it helps him in getting a fair idea about himself. On the whole it helps him to making the right decision in choosing the right path for getting involved for deciding the future course of action. This is nothing but a self-identification process. After having being properly identify his strength, weakness and ability, he can make a decision of his choice. The concept of growth theory seems to be closely related in explaining the theory of entrepreneurship development as well. After the Second World War entrepreneurship received new meaning for attaining economic development within the shortest possible time. To analyse resources utilization and Proper utilization of human potentiality, special attention to take up new activities and to create self-employment and generation of employment opportunity for better economic gain.
\end{abstract}

Keywords Entrepreneurship, Self Employment, Future Challenges

\section{Introduction}

Engineering students usually find them selves in a business environment without the knowledge of business .Many new business formations are based on technology, making it essential that engineering students are introduced to the relevant principle, process, and practises of technical entrepreneurship. Further more, the pervasive globalization of economy has dramatically changed the environment in which engineers practice today. Unfortunately, the rigorous demands of engineering students technical training, as mandated by the Nigerian universities commission as a core requirement that apply to all students, leave little opportunity in engineering curricula to prepare engineering students to function effectively in this global, entrepreneurial environment to maximize the synergism and provide more realistic learning experience that mimic entrepreneurial business practice in technical companies or start-ups.

\section{What is Entrepreneurship?}

It is the ability to organize a commercial undertaking which may involve risk, or a process through which individuals identify opportunities.

* Corresponding author:

bashirgarba2003@yahoo.com (Bashir Garba I)

Published online at http://journal.sapub.org/jmea

Copyright (C) 2012 Scientific \& Academic Publishing. All Rights Reserved
Entrepreneurship is becoming more and more acknowledged as an important driver of growth, innovation and job creation, traditional business education tends to focus on disseminating information and training of analytical abilities, whereas the vital skills for entrepreneurs are less about information processing and analysis and more about creativity and action. Engineers with entrepreneurship knowledge often become self-employed by starting new businesses compared to business graduate. The art of managing a creative group is to ensure that the condition are as conducive to good work as they can be, and only then to apply the rules of efficiency, we need to recognize that entrepreneurial activity is an inherent part of everyday life, and even the seemingly trivial activities of everyday life have great capacity to move us in new and unexpected directions.

\subsection{Entrepreneurship Theory}

A theory of evolution through economic activities and a continuous process of economic development, as an ingredient to development. Essentially a creative activity or an innovative function, a risk taking factor which is responsible for an end result usually understood with reference to individual business. The name given to the factor of production, which performs the functions of enterprise and Creates awareness among people about economic activity, Generates Self-employment and additional employment

\subsection{Why Entrepreneurship}

To improve on the backwardness of people, economic 
development of a country and to analyse resources utilization and Proper utilization of human potentiality, Special attention need to take up new activities and to create self- employment and generation of employment opportunity for better economic gain.

To process of entrepreneurship therefore passed through the potential roots of the society and all those who accepted entrepreneurial role had the cultural heritage of trade and business. Occupational pursuits opted by the individual under the caste system received different meaning of value attached to entrepreneurship. Which is based on social sanctions as society grew and the process of business occupation depended and the value work tended towards change and the various occupational roles interchanged with nonrole group and sub-groups. People from different castes and status also entered into the entrepreneurial role.

The emergence of entrepreneurship in Africa is that it got localized and spread effect, took its own time. The concept of growth theory seems to be closely related in explaining the theory of entrepreneurship development as well. After the Second World War entrepreneurship received new meaning for attaining economic development within the shortest possible time. But in the process Development of business eateries is a complex phenomenon influenced by both the internal and external factors. Internal factor originates in policies and attitude of the entrepreneur themselves, and controlling the business itself. External factors are beyond the control of the business entrepreneur. They alone account for unpredictability of returns and risks assumed by the entrepreneur. A steady growth can be observed on the business of long cherished history of entrepreneurial development in Africa certainly promised or the environment to be created by the countries in Africa The entrepreneurial motivation is one of the most important factors which accelerate the pace of economic development by bringing the people to undertake risk bearing activities. In many of the developing countries a lot of attention is being paid to the development of entrepreneurship because it is not the proprietary quality of any caste and community.

The entrepreneurship is usually understood with reference to individual business. Entrepreneurship has rightly been identified with the individual, as success of enterprise depends upon imagination, vision, innovativeness and risk taking. The production is possible due to the cooperation of the various factors of production, popularly known as land, labour, capital, market, management and of course entrepreneurship. The entrepreneurship is a risk-taking factor, which is responsible for the end result in the form of profit or loss.

According to A Schumpeter "The entrepreneurship is essentially a creative activity or it is an innovative function".

The economic activity with a profit motive can only be generated by promoting an attitude towards entrepreneurship. The renewed interest in the development of entrepreneurship to take up new venture should emphasize on the integrated approach. The developments of entrepreneurship will optimize the use of the unexploited resources; generate self- employment and a self sufficient economy.

The young entrepreneur should be motivated to come out with determination to do something of their own and also to contribute to the national income and wealth in the economy. If a country wants to achieve the growth at the grass root level, through social justice and the crimination of poverty, it will have to provide institutional support and structural changes in organization of financial institutions to promote entrepreneurship development. Industrial development in any region is the outcome of purposeful human activity and entrepreneurial thrust. David Melelland emphasized the importance of achieving motivation as the basis of entrepreneurial personality and a cause of economic and social development through entrepreneurship by fulfilling the following needs such as (1) Need for power (2) Need for affiliation and (3) Need for achievement.

Another school of thought says "entrepreneurship is a function of several factors i.e. individual socio cultural environment and support system". Entrepreneurship is vibrant assertion of the facts that individual can be developed, then outlook can be changed and their ideas can be converted into action though on organized and systematic program for entrepreneurs. It was also felt that systematic training can be given a better output and attracting people for taking up business venture can change economic scenario. Basic objective in developing entrepreneurship and multiplying them in the society has been to enable the society to generate productive human resource, mobilize and sustain the same in subsequent process of development. The spontaneity and continuity of the process would depend on the kind of people that can be prompted and groomed in the entrepreneurial career, from general population on various personality trials such as need for achievement, creativity, propensity to take risk, independence leadership etc.

Economists lighted situational characteristics such as occupational backgrounds access to capital business and technological experience and managerial skills with economic gains considered as characteristic of entrepreneur.

As entrepreneur by implication is one who ventures out, who prefers change as a means of growth and it the process that prepared one to take a calculated risk while taking risks he is aware of the possibilities of success as well as the consequence of failure.

\subsection{An Entrepreneurial Career}

Entrepreneurship plays an important role in the economic growth and development of a nation. It is a purposeful activity that includes in initiation, promotion and distribution of wealth and service. An entrepreneur is a critical factor in economic development and an integral part of the socioeconomic transformation. It is a risk taking activity and challenging tasks, needs utmost devotion, total commitment and greater sincerity with fullest involvement for his personal growth and personality. The entrepreneurial career is not a one day job nor is it bed of roses. Prosperity and success never come easily; it takes time and needs hard work, 
Systematic planning and business acumen to be successful entrepreneur. Therefore, before choosing this path one should be very careful in knowing about his own self. This introspection process helps him in knowing about himself. Every person has his own potentiality and resource. How he looks in to this aspect. If the person can understand or identify his inner traits then it helps him choosing the right path for which he should look into his beliefs, faith and values etc. For an entrepreneur it is of great importance to know about him on the basis of above mentioned individual consideration. These consideration give him ample scope to face his own self by asking the question "Who I am?" If he can give meaningful answer to this complex question with exemplary courage and utter personal disregard to being exposed, then it helps him in getting a fair idea about himself. On the whole it helps him to making the right decision in choosing the right path for getting involved for deciding the future course of action. This is nothing but a self-identification process. After having being proper identified his strength, weakness and ability, he can make a decision of his choice.

\subsection{Who is an Entrepreneur?}

$\mathrm{He}$ is a person who develops and owns his own enterprise and moderate risk to work under uncertainty for achieving the goal. He is innovative and peruses the deviant pursuits to reflect strong urge to be independent. Persistently tries to do something better and ready to face the challenges of life with determination and patient.

Exhibits sense of leadership and competitiveness with personal responsibility which are oriented towards the future and tends to persist in the face to adversity convert a situation into opportunity.

\section{Who is an Entrepreneurial Engineer?}

Is an engineer whose state of mind is oriented toward opportunity with intellectual, financial, organizational arbitrage? The times are changing engineers work for a number of firms or organization of different sizes and their work is evaluated on interdisciplinary teams concerned largely with technical feasibility but nowadays an engineer must have market technical and societal feasibility.

\subsection{An Entrepreneurial Engineer Has the Following Techniques}

-Orientation toward opportunity.

-Intellectual, financial, organizational arbitrage.

-Technical and non technical skills competence.

All the above in the following order, 1,2 \& $\mathrm{n}$ skills

Figure: order of skills

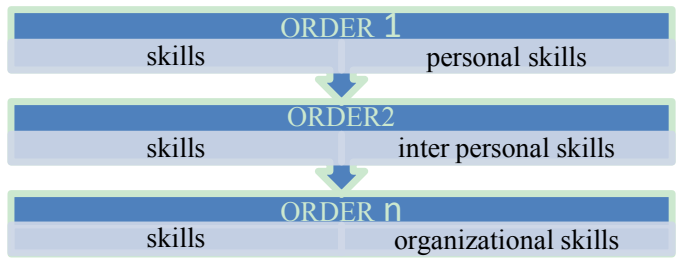

Order 1: Personal skills

Order 2: Interpersonal skills, between you and another

Order n: Organizational skills, between you and the many

\subsection{Hope is not a Strategy in Engineering}

Hope is not a strategy for success. Your life is too precious and important to be left to chance. Your greatest responsibility is to take command of your future and shape your destiny the way you want it, to do something wonderful with your life. As an engineer pleasant words and warm feelings are meaningless if there is no achievement, we work as a team to produce results and our attention is focused on seeing that we work as a team to accomplish our goals.

\subsection{Steps on your Own Accelerator}

Once you have decided to do something new or different, especially to create your own future through ideas and innovation, you want to get on with it as quickly as possible. That's the way it should be to step on the accelerator of your own dream, and how to achieve your goals faster than you ever dreamed possible. Practical, proven methods

that work for everyone who uses them, and will give you the most powerful and popular tools and techniques for personal and career success ever discovered, the same strategies used by all successful people, in every field of engineering are almost the same.

\subsection{The Law of Probabilities in Engineering}

The Law of Probabilities is the critical factor in explaining luck. This law says that for every event, there is a probability of that event occurring under certain circumstances where the level of probability can be established with some accuracy, the level of predictability can be dramatically increased. For example, if you flip a coin, it will come down heads 50 percent of the time and tails 50 percent of the time. The probability of a head or a tail is 50 percent, no matter how many times you flip the coin. You may flip the same coin five thousand times, and on every flip of the coin, the probabilities remain 50 percent. You can, therefore, predict the outcomes over time with complete accuracy.

\subsection{An engineer Becomes Brilliant on the Basics}

If you want to achieve success in any engineering field, and you have a clear, written plan that you follow and work on each day, you are much more likely to attain it. If you then study thoroughly and apply yourself to developing the knowledge and skills necessary to excel in your field, you will increase your probabilities of success. If you associate with the right people, manage yourself and your time extremely well, move quickly when you Can Improve your Likelihood of Success opportunity will presents itself, persevere in the face of obstacles, you will get the breaks. Willingness to take intelligent risks in the pursuit of your clearly defined, intensely desired goals puts you on the side of the angels. You will increase all the possible probabilities in your favour. You will achieve the same level of success in 
one or two years that other people may not achieve in 10 or 20 years of less focused, less directed behaviour. You will create your own future.

\subsection{Invention}

An invention is a new idea of an inventor, which permits in practice a solution of specific problem in the field of technology. An invention may be or may relate to a product, a device, a substance or a process and is normally patentable if it is new, involved an inventive step and is industrially applicable.

\subsubsection{Inventor}

An inventor is the person who makes an invention, or one who first conceive of an invention, in detail and with enough specificity that one skilled.

\subsubsection{Innovation}

In a broad sense innovation covers the whole process of creation, development, and application, commercialization of new ideas, products and processes in any branch of the economy. Innovation is a practical solution to technological problem of a specific enterprise, which is new for that enterprise. It is also the result of a complex process involving the transformation of an invention into an industrial product or process.

\subsubsection{Technovation}

A solution to a specific problem in the field of technology proposed by an employee of an enterprise for use by that enterprise, and which relates to the activities of the enterprise but which, at the date of proposal, has not been used or actively considered for use by that enterprise.

\subsubsection{Creativity}

Creativity can be defined as a combination of novelty and appropriateness and has been associated with problemsolving and novelty generation as well as with reactive and adaptive behaviour that allows people to cope up with turbulent environments. Even if psychological perspective are most common, one common way of structuring creativity research is to divide it into person, process, product and press, where the person approach includes research on personal characteristics and traits; process research is more behav- ioural and involves creative thinking and techniques: research on creative products can be investigated through measures of their quality and quantity and press refers to factors within and especially outside individuals which affect the creativity.

\section{Conclusions}

Entrepreneurial engineers most have a Strategic plan to become his blueprint for the future of his or her organization. It gives you a clear track to run on, and benchmarks against which to measure success. A strategic plan can only be achieve through proper understanding of the entrepreneurship it self and how it can be applicable technically in various field of engineering through innovation creativity and to focus on high value activities. Once you have a list of activities, select at least one and take action on it immediately. From the first time you take action on your list you will begin to see progress.

\section{REFERENCES}

[1] W.Bradly,and A.Grinols,G.Blalock,W.Jordan,G.Leman and C.Fry Incorporating Global Entrepreneurship Courses into an Engineering Curriculum www.nciia.org.2011

[2] Cassel,T.A.V Engineering entrepreneurship at Penn.ASEE Annual conference Proceedings,2003ASEE Annual conference and Exposition: Staying in Tune with Engineering Education 1266-12678

[3] Creed,C.J.,E.M.Suuuberg, and G.P.Crawford.2002.Journal of Engineering Education 91(2):185-195

[4] Bashir Garba.I. The Entrepreneurial Engineer.Lambert Academic Publishing 2011

[5] www.allfreeessays.com/topics/achievement-motivation2011

[6] www.freepatentsonline.com/article/Academy-Entrepreneurs hip-Journal/166778547

[7] www.csis.org/publication/entrepreneurship-india-next-wave

[8] www.papers.ssrn.com/sol3/JELJOUR_Results.cfm?form_na me=journalbrowse\&journal_id=872284 